\title{
A system for the control and recording of physical parameters inside a chamber for UV-C irradiating of biological material
}

\author{
Tomasz Jakubowski ${ }^{1}$ \\ ${ }^{1}$ University of Agriculture in Krakow, Institute of Machine Operation, Ergonomics and Production \\ Processes
}

\begin{abstract}
This paper presents a system for the control and recording of physical parameters inside a chamber for UV-C irradiating of biological material. The system was based on the HOBO U23-002 temperature and humidity recorder equipped with an integrated external probe, BASE-U-4 optical reader for programming and reading data from HOBO U series recorders, LIGHT METER radiation meter UVC-254 model equipped with a photodiode probe (LP UV-C 01) with a sensitivity of $0.19 \mu \mathrm{W} \cdot \mathrm{cm}^{-2}$ and sampling time $0.4 \mathrm{~s}$, HOBOware Lite software (for archiving temperature and relative humidity measurement results) with a PC, RS-232 serial interface and dedicated software (SWU-801 LUTRON and SW-U101WIN) enabling interaction with the meter (for archiving UV-C radiation measurements) and a PC. The operation of the system was tested in real operating conditions of the chamber, by irradiating potato tubers of Innovator variety at different settings of the UV-C radiator. The data obtained was analysed against the significance level assumed of $\alpha=0.05$. Significant influence of the qualitative predictors on the dependent variables examined was shown.
\end{abstract}

\section{Introduction}

Modern agriculture requires the search for safe to human and the environment ways to improve the production efficiency in connection with the quality of yield [1-6]. This approach is in line with the European Union guidelines and the European Parliament's regulations regarding the restrictions on the use of chemical plant protection products and agents improving their yield [7-8]. The ways to improve the production efficiency and the quality of yield, while maintaining the safety of application, can be sought among the methods of physical stimulation of biological material [9]. Currently, physical methods are applied in food technology as a way to eliminate or reduce the population of bacteria which affects the longevity and safety of the food product. C-band UV radiation has been used in food sterilisation processes or as a method of plant protection (patent US 2009/0272029 A1). Páez [10] used this physical method to kill grain mycobiota, and applied UV-C irradiation of potato plants in order to induce symptoms of abiotic stress. Błażejak [11]

${ }^{1}$ Corresponding author: tomasz.jakubowski@ur.krakow.pl 
conducted research on the use of ultraviolet radiation to obtain Gluconacetobacter xylinus mutants which were then used to perform biotransformation of glycerol into DHA (the best of the mutants synthesised $18.00 \mathrm{mg}$ DHA $\mathrm{cm}^{-3}$, i.e. $32 \% \mathrm{DHA}^{-3} \mathrm{~cm}^{-3}$ more than the parental strain). With regard to potato, the influence of UV-C radiation was examined in respect of its impact on seed potatoes of the Jelly variety and the subsequent course of the ontogensis of plant [12-15].

In the work of Jakubowski et al. [12], on the effectiveness of UV-C radiation influence on the development of potato tuber rhizoctonia, the structure and basic specifications of a stand for testing on the C-band ultraviolet influence on biological objects was presented. Inside the chamber, measurements of light intensity, temperature and relative humidity were made. The tests were aimed at determining the time needed for stable operation of the UV-C radiator. Sensors (probes) of measuring instruments were located in nine points (IIX) at the bottom of the chamber, for measuring the light intensity taking into account the applicable standard [PN-EN 12464-1: 2004], and in three points (I, IV, VIII) for temperature and humidity measurements, according to the diagram shown in figure 1.

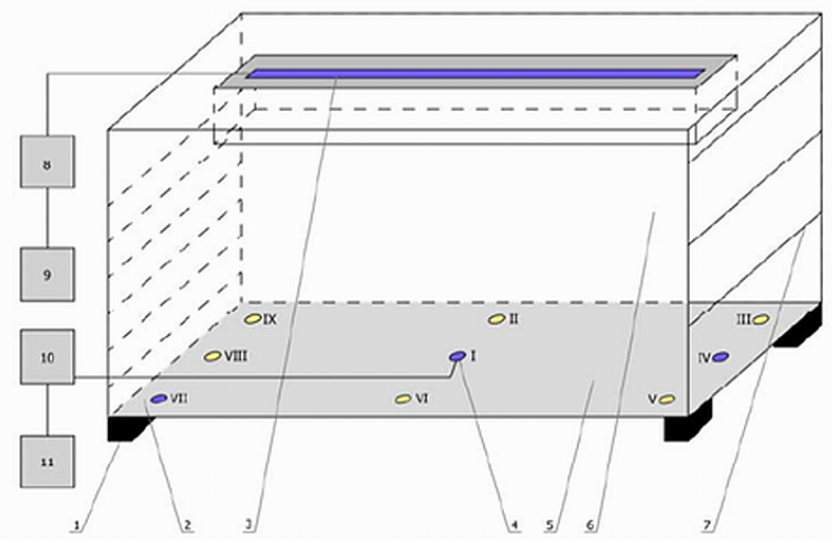

Fig. 1. Test stand to UVC exposure of potato tubers: 1 - props, 2 - bottom of the chamber, 3 - UVC radiator, 4 - placement of sensors (I-IX), 5 - location of potato tubers, 6 - inside the chamber, 7 UVC radiator height adjustment, 8 - timer, 9 - power source, 10 - multimeter, 11 - data logger

In the above-mentioned experiment [12] the parameters (relative temperature and humidity as well as light intensity) of the chamber interior were examined without of biological objects and with the use of less technologically advanced tools than those described in this paper. The major objective of the work was to present a system the control and recording (archiving) of physical parameters (relative temperature and humidity and the intensity of the C-band ultraviolet radiation) inside the chamber for UV-C irradiation of biological material. It was also sought to present the results obtained while testing the aforementioned system in real operating conditions of the chamber (containing biological material).

\section{Scope of work, test method and tools}

The tests were carried out in 2018 using a stand for UV-C irradiating of biological material (fig. 1) equipped with a system to control the chamber operating parameters (fig. 2). The subject of the tests inside the chamber were: relative temperature and humidity, and the ${ }^{1}$ Corresponding author: tomasz.jakubowski@ur.krakow.pl 
intensity of UV-C radiation. The probes were located in the middle of the bottom of the chamber at point I (fig. 1). The tests were performed during irradiation of biological material and without this material. Potato tubers of the Innovator variety were used as the biological material. The variability of the sample of randomly selected tubers, determined by the quotient of the standard deviation and an average weight of a single tuber, ranged from 18.2 to $24.1 \%$. The choice of the variety was due to the experiments performed then by the authors on the impact of UV-C on raw material intended for the production of fried potato products in terms of its colour and acrylamide content after the thermal processing. The system for the control of the chamber operating parameters comprised (fig. 2):

- HOBO U23-002 temperature and humidity recorder equipped with an integrated external probe, BASE-U-4 optical reader for programming and reading data from $\mathrm{HOBO} \mathrm{U}$ series recorders;

- LIGHT METER radiation meter model UVC-254 equipped with a photodiode based probe (LP UV-C 01) with a sensitivity of $0.19 \mu \mathrm{W} \cdot \mathrm{cm}^{-2}$ and sampling time $0.4 \mathrm{~s}$;

- HOBOware Lite software (for archiving temperature and relative humidity measurement results) with a $\mathrm{PC}$,

- RS-232 serial interface and dedicated software (SWU-801 LUTRON and SW-U101WIN) enabling interaction with the meter (for archiving UV-C radiation measurements) and a PC.

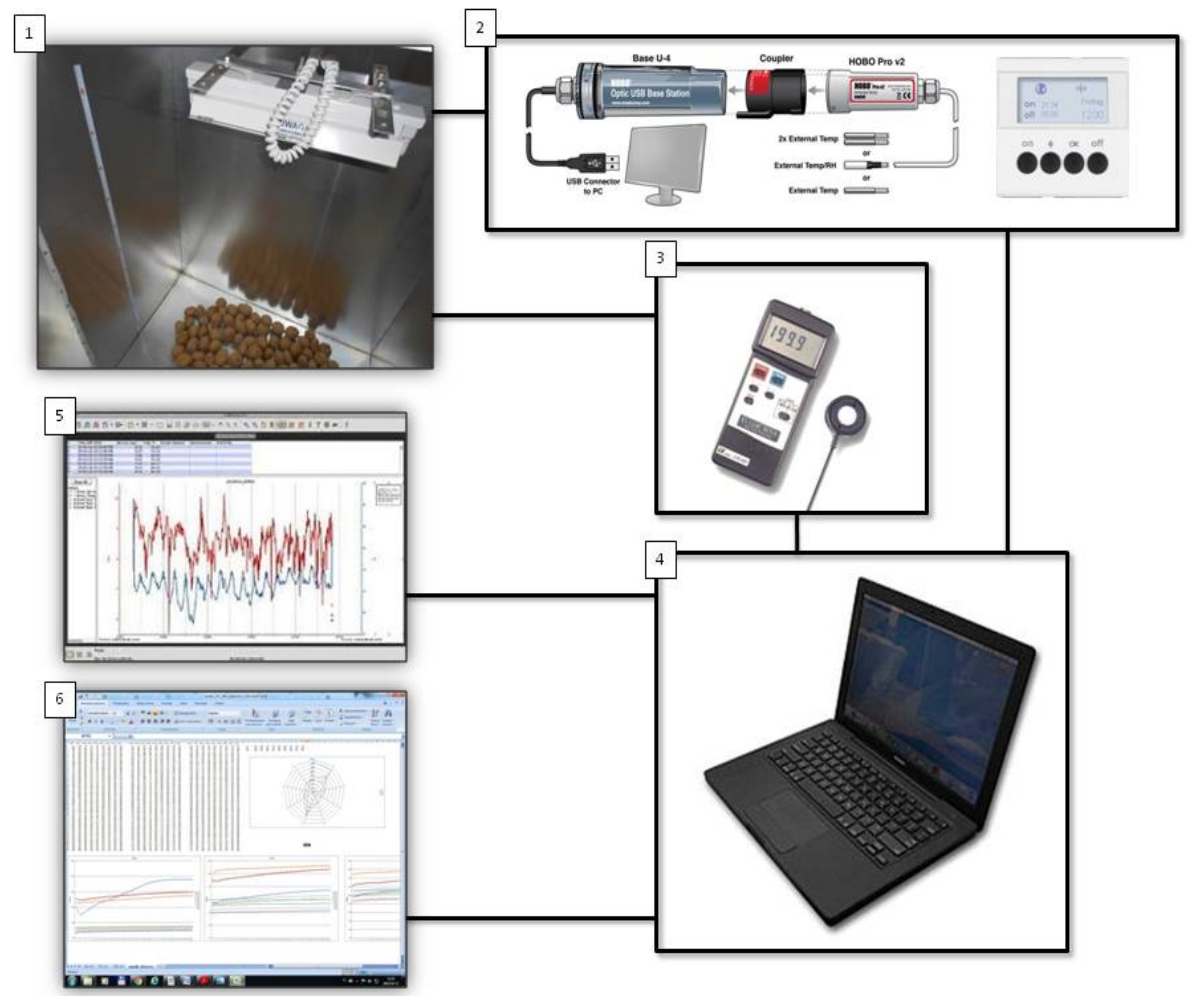

Fig. 2. System for the control and recording parameters inside a chamber for UV-C irradiating of biological material: 1 - chamber for UV-C irradiating of biological material, 2 - HOBO U23-002 temperature and humidity recorder, 3 - LIGHT METER radiation meter, 4 - PC, 5 - HOBOware Lite software, 6 - SWU-801 LUTRON and SW-U101-WIN,

${ }^{1}$ Corresponding author: tomasz.jakubowski@ur.krakow.pl 
During the measurements, the test stand was located in a laboratory room with an ambient temperature $19.2^{\circ} \mathrm{C}$ and the relative humidity $53.5 \%$. The conditions inside the chamber before the start of the research were identical to the ambient ones. The experiment was carried out in two stages; during stage I, the physical parameters of the empty chamber were examined and in the stage II, the biological material was used. In both, the first and the second stage, the operating time of the chamber with an active UV-C radiator was dependent on obtaining its stability in terms of the physical parameters tested. It was arbitrarily assumed that the chamber worked in a stable manner when 10 consecutively measured values of a given physical parameter did not show variations above $5 \%$. Measuring step of $1 \mathrm{~s}$ was assumed. The following heights of the UV-C radiator were used above the bottom of the chamber: $0.4,0.7$ or $1.0 \mathrm{~m}$. The test stand (fig. 1) is a rectangular chamber with a volume of $0.63 \mathrm{~m}^{3}(0.55 \times 0.95 \times 1.2)$ made of wood, the inner walls of which were covered with aluminium foil. It is equipped with a 15 watt NBV15 UV-C radiator with a precise timer (AURATON 100). The height of the radiator above the chamber is adjustable in the range from $1.0 \mathrm{~m}$ to $0.4 \mathrm{~m}$. The lifetime of the NBV15 radiator, maintaining its operating parameters unchanged, is $8,000 \mathrm{~h}$ (the intensity of $\mathrm{UV}-\mathrm{C}$ radiation at a distance of $1 \mathrm{~m}$ from the radiator is $0.9 \mathrm{~W} \cdot \mathrm{m}^{-2}$ ). The radiator is equipped with a reflector made of high-quality aluminium with a high reflectivity (characteristics close to that of a mirror). Potato tubers during the irradiation are located on a flat, wooden bottom with an area of $0.52 \mathrm{~m} 2(0.55 \times 0.95)$. The data obtained was analysed using the STATISTICA 13.3 package at the assumed significance level of $\alpha=0.05$. Tested was the normality of the distribution of variables in populations (Shapiro-Wilk test) and homogeneity of variance (Levene test). The variance for the main effects of the experiment was performed (together with testing the effect of interaction between quality predictors) based on the value of the Wilks test and F-Snedecor statistics. For statistically significant grouping variables, post-hoc tests were carried out using the Duncan test. Groups of homogeneous variables were determined (in the tables marked with ***).

\section{Results of tests and discussion}

The tested samples had normal distribution and homogeneous variances. The analysis of variance showed a significant value of the $F$ test of main effects, while no statistically significant interaction effect was found (table). The Duncan test result showed a significant effect of the chamber load on the relative humidity (table) measured inside it and the height of the UV-C radiator on all studied dependent variables (table). For the chamber filled with plant material, significantly higher relative humidity, compared to that without the material, was demonstrated. That phenomenon may result from life processes (transpiration and respiration) of a potato tuber. Relative humidity and temperature values (table) decreased as the distance of the UV-C radiator from the bottom of the chamber increased (at the same time, as the temperature increased, the relative humidity value decreased). Such a thermodynamic phenomenon was expected because the increase of temperature, without changing the water vapour content, is accompanied by a decrease in relative humidity. The value of radiation intensity decreased as the distance of the UV-C radiator from the bottom of the chamber (table) increased, which is due to the fact that the light intensity is the quotient of the luminous flux falling on the elementary surface and the value of said surface. Assuming the point character of the light source, the intensity of light depends on the luminous intensity towards the point at which the light intensity is examined, the distance from the source to that point, the angle between the normal and the direction of light falling and the height of the source of this light over the considered plane. After

${ }^{1}$ Corresponding author: tomasz.jakubowski@ur.krakow.pl 
approximately 46 seconds since the chamber operation was started, no changes in UV-C intensity were found (Fig. 3).

Table 1. Results of the analysis of variance - the effect of the chamber loading and the height of the UV-C radiator on the value of relative temperature and humidity and radiation intensity

\begin{tabular}{|c|c|c|c|}
\hline Qualitative predictor & Wilks test value & F-Snedecor test value & Test probability \\
\hline Word free & 0,000097 & 1235225 & 0,0000 \\
\hline Chamber filling $\{1\}$ & 0,958941 & 5 & 0,0018 \\
\hline Heater height $\{2\}$ & 0,152981 & 186 & 0,0000 \\
\hline Interaction $\{1\}^{*}\{2\}$ & 0,993602 & 0 & 0,8897 \\
\hline
\end{tabular}

Table 2. System of homogeneous groups - the effect of the UV-C chamber loading on the relative humidity

\begin{tabular}{|c|c|c|c|}
\hline Chamber filling & Humidity (\%) & \multicolumn{2}{|c|}{ Homogeneous groups } \\
\cline { 3 - 4 } & & 1 & 2 \\
\hline empty & 54,07 & $* * *$ & \\
\hline with potato tubers & 54,27 & & $* * *$ \\
\hline
\end{tabular}

Table 3. System of homogeneous groups - the effect of the UV-C radiator height on the relative humidity

\begin{tabular}{|c|c|c|c|c|}
\hline Heater height (m) & Humidity (\%) & \multicolumn{3}{|c|}{ Homogeneous groups } \\
\cline { 3 - 5 } & & 1 & 2 & 3 \\
\hline 1,0 & 53,85 & $* * *$ & & \\
\hline 0,7 & 54,18 & & $* * *$ & $* * *$ \\
\hline 0,4 & 54,48 & & & $*$ \\
\hline
\end{tabular}

Table 4. System of homogeneous groups - the effect of the UV-C radiator height on the relative temperature

\begin{tabular}{|c|c|c|c|}
\hline \multirow{2}{*}{ Heater height $(\mathrm{m})$} & Temperature $\left({ }^{\circ} \mathrm{C}\right)$ & \multicolumn{2}{|c|}{ Homogeneous groups } \\
\cline { 3 - 4 } & & & 2 \\
\hline 1,0 & 20,92 & $* * *$ & \\
\hline 0,7 & 21,40 & $* * *$ & \\
\hline 0,4 & 21,43 & $* *$ \\
\hline
\end{tabular}

Table 5. System of homogeneous groups - the effect of the radiator height on the intensity of UV-C radiation

\begin{tabular}{|c|c|c|c|c|}
\hline Heater height $(\mathrm{m})$ & Radiation intensity & \multicolumn{3}{|c|}{ Homogeneous groups } \\
\cline { 3 - 5 } & $\left(\mu \mathrm{W} \cdot \mathrm{cm}^{-2}\right)$ & 1 & 2 & 3 \\
\hline 1,0 & 56,51 & $* * *$ & & \\
\hline 0,7 & 87,01 & & $* * *$ & $* * *$ \\
\hline 0,4 & 150,03 & & & \\
\hline
\end{tabular}

${ }^{1}$ Corresponding author: tomasz.jakubowski@ur.krakow.pl 


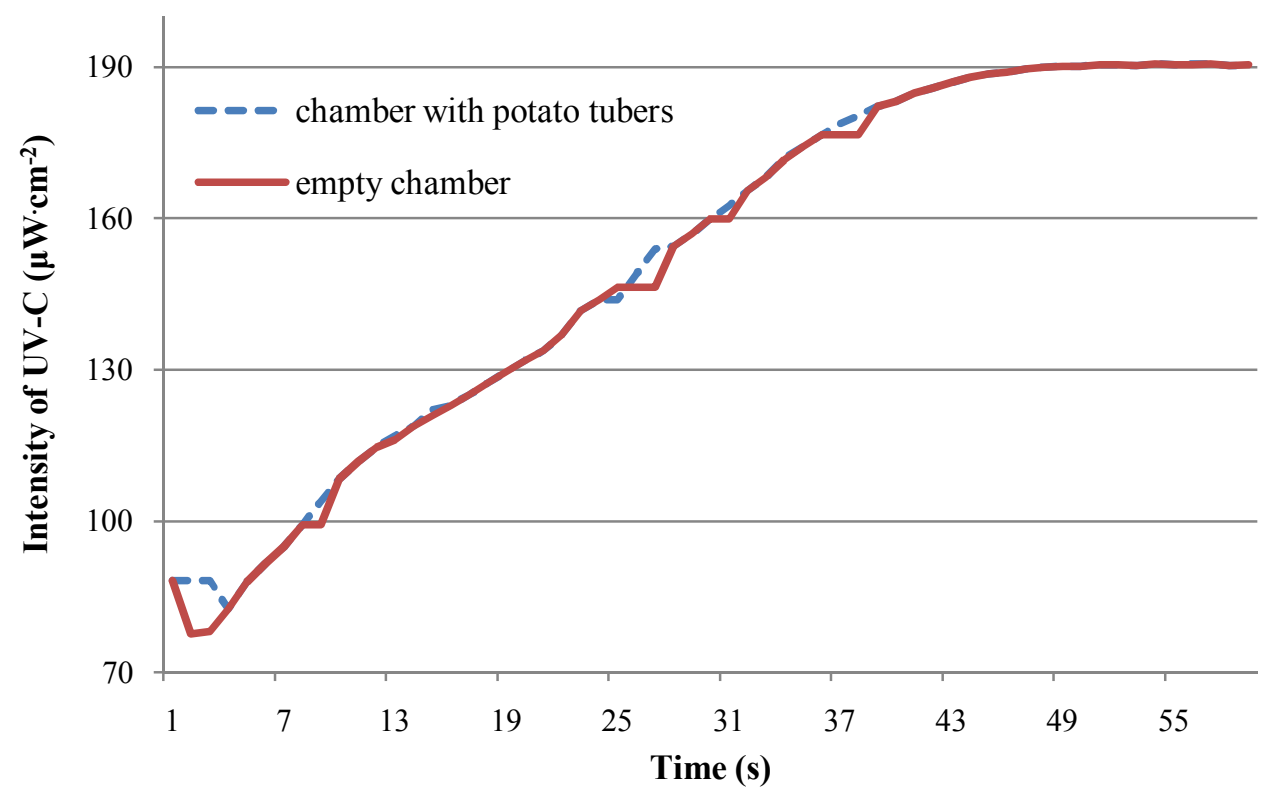

Fig. 3. Change of the UV-C radiation intensity vs. time

\section{Summary}

The proposed solution based on the HOBO U23-002 temperature and humidity recorder (equipped with an integrated external probe, BASE-U-4 optical reader for programming and reading data from HOBO $U$ series recorders) and LIGHT METER radiation meter model UVC-254 (equipped with a LP UV-C 01 photodiode based probe with a sensitivity of $0.19 \mu \mathrm{W} . \mathrm{cm}^{-2}$ ) can constitute a control system for physical parameters inside the chamber for UV-C irradiating biological material. The software interacting with the control system (HOBOware Lite, SWU-801 LUTRON and SW-U101-WIN) properly archives the measurement data obtained and enables its analysis.

\section{References}

1. Urva, H. Shafique, Y. Jamil, Z. ul Haq, T. Mujahid, A. Khan, M. Iqbal, M. Abbas, Journal of Photochemistry and Photobiology, 170, 314-323 (2017).

2. L. Sivachandiran, A. Khacef, Royal Society of Chemistry Advances, 7, 1822-1832 (2017).

3. H. Ran, L. Yang, Y. Cao, Agricultural Sciences, 6 7, 670-675 (2015).

4. E. Ozden, R. Delialioglu, H. Albayrak, S. Hussein, I. Demir, Seed Science and Technology, 45, 465-474 (2017).

5. A. El Shokali, A. Abdelbagi, M. Abdallah, Journal of Basic and Applied Sciences, 11, 440-444 (2015).

6. F. Aghamir, H. Bahrami, M. Malakouti, S. Eshghi, American Journal of Life Science Researches, 3 2, 184-195 (2015).

${ }^{1}$ Corresponding author: tomasz.jakubowski@ur.krakow.pl 
7. Dyrektywa Rady $93 / 85 /$ EWG z dnia 4 października 1993 r. w sprawie zwalczania bakteriozy pierścieniowej ziemniaka, która określa szczegółowe zasady zwalczania tej bakterii i zapobiegania jej rozprzestrzenianiu się.

8. Dyrektywa Rady 2000/29/WE z dnia 8 maja 2000 r. w sprawie środków ochronnych przed wprowadzaniem do Wspólnoty organizmów szkodliwych dla roślin lub produktów roślinnych i przed ich rozprzestrzenianiem się we Wspólnocie, zgodnie z którą bakteria ta ma status organizmu kwarantannowego i podlega obowiązkowi zwalczania.

9. T. Jakubowski, Z. Sobol, B. Łapczyńska-Kordon, J. Sikora, D. Baran, Wybrane aspekty przechowywania bulw ziemniaka $w$ kontekście jakości surowca. (red.) T. Jakubowskiego, Wydawnictwo PTIR Kraków, (2016)

10. Páez, M. Reyes, C. Aguilar., F. Pacheco, E. Martíne, A. Orea, J. Bonilla, Acta Agrophysica, 18 2, 375-388 (2011).

11. S. Błażejak, L. Stasiak-Różańska, K. Markowski, E. Lipińska, Acta Sci. Pol., Biotechnologia 10 2, 17-24 (2011).

12. T. Jakubowski, T. Pytlowski, Inżynieria Rolnicza. 3 145, 99-107 (2013).

13. T. Jakubowski, T. Pytlowski, Inżynieria Rolnicza, 2 154, 35-43 (2015).

14.Z. Kowalczyk, M. Cupiał, Contemporary Research Trends in Agricultural Engineering BIO Web Conf., 10 (2018).

15. M. Cupiał, Z. Kowalczyk, Contemporary Research Trends in Agricultural Engineering BIO Web Conf., 10 (2018).

${ }^{1}$ Corresponding author: tomasz.jakubowski@ur.krakow.pl 